\title{
Dabigatran Use Associated with Hemopericardium and Hemothorax
}

\author{
Josip Katić1, Marko Skelin², Ana Katićc , Karla Katić4, Ružica Avelini Perković1, Dario Rahelić́, \\ Jure Mirat' \\ ${ }^{1}$ Department of Cardiovascular Diseases, University Hospital Split, Split, Croatia \\ ${ }^{2}$ Department of Pharmacy, General Hospital Sibenik, Sibenik, Croatia \\ ${ }^{3}$ School of Medicine, University of Split, Split, Croatia \\ ${ }^{4}$ Department of Ophthalmology, University Hospital Center Split, Split, Croatia \\ ${ }^{5}$ Clinic for Diabetes, Endocrinology and Metabolic Diseases, Merkur University Hospital, Zagreb, Croatia \\ ${ }^{6}$ School of Medicine, Josip Juraj Strossmayer University, Osijek, Croatia
}

\begin{abstract}
A B S T R A C T
Concurrent spontaneous hemopericardium and hemothorax due to anticoagulant use are extremely rare in clinical practice. Dabigatran is an oral direct thrombin inhibitor approved to prevent stroke or thromboembolic episodes in patients with nonvalvular atrial fibrillation. We report the case of a 73-year-old man who received dabigatran therapy (150 mg twice a day) for 3 months and developed massive spontaneous hemothorax and hemopericardium associated with fever. Emergency chest computed tomography scan established higher-density pericardial effusion (22HU) and left pleural effusion of heterogeneous density (5-15 HU) which could be hemorrhagic content while the heart ultrasound finding confirmed pericardial effusion 7-9 mm thick, without affecting hemodynamics. Almost $1100 \mathrm{~mL}$ of blood was drained by ultrasoundguided thoracentesis. After excluding other possible causes, diagnostic withdrawal was performed for dabigatran and no further pleural or pericardium effusion developed after dabigatran was discontinued. Therefore, practitioners could be aware of hemothorax as well as hemopericardium as a potential complication of dabigatran therapy.
\end{abstract}

Key words: dabigatran, hemopericardium, hemothorax, atrial fibrillation, anticoagulation

\section{Introduction}

Atrial fibrillation (AF) is the most common cardiac arrhythmia, and it is a significant cause of cardiovascular disease and mortality worldwide ${ }^{1}$. AF incidence is predicted to increase 2 to 3 times by $2050^{1}$. Patients with AF have a 5 times higher risk of stroke, but this risk is not homogeneous considering the presence of specific stroke risk factors / modifiers. For instance, non-paroxysmal AF is associated with a higher incidence of stroke compared to paroxysmal $\mathrm{AF}^{2}$. The most common causes of stroke in patients with AF are incorporated into the CHA2DS2VASc score, which is used to assess the risk of thromboembolic (TE) incident and the decision to introduce anticoagulant therapy according to the latest AF treatment guidelines ${ }^{1}$. The introduction of anticoagulant therapy should be considered in men with 1 , and women with 2 points; while it is certainly indicated for men with $\geq 2$ points, and for women with $\geq 3$ points according to CHA2DS2-VASc ${ }^{1}$. However, in addition to assessing the risk of TE, the risk of bleeding should initially be assessed with HASBLED as recommended scoring system ${ }^{3}$.

Warfarin has been the foundation of anticoagulant therapy used worldwide for many years. One of the main limitations of warfarin administration is the narrow therapeutic interval assuming INR values between 2 and 3 , the need for regular prothrombin time monitoring and frequent dose adjustment ${ }^{4}$. Furthermore, warfarin interacts with various foods (e.g. green vegetables) and drugs, which affects the stability of the anticoagulant effect. The solution to a number of problems related to vitamin $K$ antagonists has been provided by newer anticoagulant drugs that are increasingly used in clinical practice. Direct oral anticoagulant (DOAC) therapy is the foundation of care for a patient with AF, largely due to a beneficial effect on long-term prognosis. DOAC therapy prevents ischemic strokes and reduces overall mortality ${ }^{5}$. All of the evaluated direct oral anticoagulants (DOACs) (dabigatran, rivaroxaban, apixaban, and edoxaban) were either noninferior or superior to warfarin therapy in reducing

Received for publication September 12, 2020 
the risk of stroke or systemic embolism (SE) in patients with NVAF (non-valvular atrial fibrillation) ${ }^{6-9}$. However, bleeding that may occur during their use is a concerning side effect. In patients with NVAF, DOACs have a significantly lower risk of bleeding complications as well as intracranial hemorrhage compared to the same cases treated with warfarin ${ }^{10}$. Patients treated with anticoagulant drugs make up a significant percentage of patients in emergency departments. Their treatment is very challenging considering their increased risk of bleeding or increased risk of thromboembolism in case of discontinuation of anticoagulant therapy.

In this case report we describe a man with AF who developed both hemothorax and hemopericardium due to dabigatran use.

\section{Case Report}

The 73-year-old man (height, $190 \mathrm{~cm}$; body weight, 112 $\mathrm{kg}$; body mass index (BMI), $31.0 \mathrm{~kg} / \mathrm{m}^{2}$ ) was admitted to the emergency department complaining of increased shortness of breath and history of subfebrile condition. He had a known diagnosis of NVAF with repeated cardioversions in the last two months prior to this admission, chronic obstructive pulmonary disease, hypothyreosis and ischemic cardiomyopathy with stents implanted in the proximal left anterior descending artery (LAD). Before admission, a planned electrophysiology study has been canceled due to unexpected fever. Approximately 3 months before admission, the patient had been prescribed dabigatran etexilate $150 \mathrm{mg}$ orally twice a day (CHA2DS2-VASc 3 , HASBLED 3). His other drug therapy consisted of levothyroxine, diuretics, tamsulosin and bisoprolol.

In January 2019 he became subfebrile with noticed increase in inflammatory parameters. Several antibiotics were changed, but without effect on clinical response and/ or change in biomarkers. He was conscious with hemodynamic stability and afebrile. The clinical examination of the respiratory system and heart examination revealed reduced breath sounds and dullness to percussion at the left low base, with regular heart sounds, but no pathological murmur. A summary radiological image of the thoracic organs showed the left lower pulmonary field homogeneously shaded with applanation of the associated hemidiaphragm in terms of the pleural component. Emergency multi-slice computed tomography (MSCT) of the pulmonary artery ruled out embolization, but established higher-density pericardial effusion (22HU) and left pleural effusion of heterogeneous density (5-15 HU) which could be hemorrhagic content. The patient's serum creatinine concentration at this time was $103 \mathrm{umol} / \mathrm{l}$ and hemoglobin level of $134 \mathrm{~g} / \mathrm{l}$ together with C-reactive protein (CRP) on admission $131 \mathrm{mg} / \mathrm{l}$ and at discharge $30 \mathrm{mg} / \mathrm{l}$. The patient was hospitalized at the Clinic for Cardiovascular Diseases where additional diagnostic procedures were carried out. The patient underwent thoracentesis in which $1100 \mathrm{ml}$ of mild hemorrhagic effusion was drained. During hospitalization, dabigatran was excluded due to its probable association with pericardial and pleural effusions, and low molecular heparin was introduced. During the next ultrasound examination, the circumscribed effusion around the heart slowly receded. Patient was discharged with another drug from DOAC class (apixaban $5 \mathrm{mg}$ twice daily) and after 4-5 weeks echocardiography revealed a pericardium without effusion and without recurrence of hematothorax. Through 1-year follow up period given therapy had beneficial effect without subsequent complications.

\section{Discussion}

Dabigatran is the first oral anticoagulant approved for $\mathrm{AF}$ after 50 years of using warfarin and other drugs ${ }^{11}$. It is a direct and competitive inhibitor of free and bound thrombin, with predictable pharmacokinetics. It does not react with food, and has little potential to react with other drugs ${ }^{12,13}$. Dabigatran half-life in the body is $12-17 \mathrm{~h}$, therefore dosing twice a day reduces the variability of the anticoagulant effect ${ }^{13}$. Dabigatran has been given an advantage over previous drugs in the treatment of AF based on the results of the RE-LY study, which demonstrated a significant treatment-by-age interaction ${ }^{11}$. Compared with warfarin, both dosages of dabigatran (150 and $110 \mathrm{mg}$ twice a day) were associated with minor bleeding risk in patients $<75$ years old. However, in patients $\geq 75$ years old, dabigatran $150 \mathrm{mg}$ twice a day was associated with a higher rate of major bleeding, and dabigatran $110 \mathrm{mg}$ twice a day had a similar risk of bleeding13.

Annually $2 \%$ of AF patients receiving any anticoagulant therapy have severe bleeding as a side effect ${ }^{1}$. As dabigatran is increasingly prescribed in the treatment of NVAF, the number of its adverse events has also increased $^{14}$. Barton et al. were the first to describe hemopericardium as a side effect of dabigatran in the United States in the 2012. In their paper they described a 70-year-old man was taking dabigatran at a dose of $150 \mathrm{mg}$ twice a day for 2 months and consequently developed hemopericardium as a side effect of dabigatran ${ }^{14}$. Abdallah et al. reported a case of a 63-year-old man with atrial fibrillation who was on dabigatran $150 \mathrm{mg}$ therapy. On diagnostic imaging before ablation, he was diagnosed with a large pericardial effusion and a left pleural effusion. This was the first case described in the US where the same patient had pleural and pericardial effusion as a side effect of dabigatran ${ }^{15}$.

In our case an extended systematic and multidisciplinary investigation during hospitalisation was performed. We revealed no peculiarities, and therefore all possible secondary causes were rejected. Our patient did not take any medication which inhibits CYP3A4 and CYP3A5 as well as P-glycoprotein or medications that interact with and alter the pharmacokinetics and bioavailability of other drugs, potentially limiting the safe use of dabigatran. The Thrombin Time Assay was not measured, and hospitals coagulometers that are currently available were not sensitive enough to measure Thrombin Time in patients receiving dabigatran. Also, we did not measure the dabigatran serum concentration. To our knowledge, both tests for monitoring coagulation cascade in patients receiving dabigatran are not FDA-approved. Febrile reac- 
tions could be explained as absorption fever during hemothorax and pericardial effusion.

In the literature, hemothorax in the setting of treatment with warfarin, heparin and low molecular weight heparin as well as other anticoagulant therapies has been well-documented ${ }^{16-18}$. Most cases usually occured within the first week from starting the anticoagulation therapy, but they may also occur later in time. Moderate spontaneous hemothorax in the right lung after receiving $110 \mathrm{mg}$ of dabigatran twice a day for 1.5 years has been developed in 72-year-old male as well as in 63-year-old woman who received dabigatran for 8 weeks, causing sanguineous pericardial effusion and left pleural effusion ${ }^{15,19}$. Our patient was exposed to a new anticoagulant, dabigatran, for 3 months before this clinical presentation.

In our case, dabigatran led to pleural and pericardial effusion. Following thoracentesis, the patient was hemodynamically stable and there was no need to introduce fresh frozen plasma or idarucizumab, a novel antidote for reversal of dabigatran effect, while pericardial effusion was monitored regularly by ultrasound without evidence of hemodynamic compromise. Namely, idarucizumab is one of available solutions that is recommended for reversing the anticoagulant effect of dabigatran in life-threatening bleeding due to its rapid action and its effectiveness in 88 to $98 \%$ of patient ${ }^{20,21}$. However, obesity influence on absorption, excretion, pharmacokinetics and pharmacodynamics of various anticoagulants could be significant association with higher risks of stroke/bleeding depending on DOAC subtype ${ }^{22,23}$. Evidence exists that the risk for ischemic stroke event amongst obese patients dabigatran anticoagulated are significantly higher in comparison to warfarin anticoagulated patients ${ }^{24}$.

\section{Conclusion}

Our report adds to the growing evidence that DOACs may be associated with major bleeding consequences such as pleural and pericardial effusion. The aim of this case report was to raise awareness of possible serious bleeding associated with dabigatran, so that not only physicians, but also patients could recognize bleeding-related symptoms. This could facilitate prompt responses which would improve patient outcomes.

\section{Acknowledgements}

We thank the patient described for allowing us to share his details and providing informed consent. The study did not receive any specific grant from funding agencies in the public, commercial, or not-for-profit sectors.

\section{R E F E R E N C E S}

1. HINDRICKS G, POTPARA T, DAGRES N, ARBELO E, BAX JJ, BLOMSTRÖM-LUNDQVIST C, HINDRICKS G, POTPARA T, DAGRES N, ARBELO E, BAX JJ, BLOMSTRÖM-LUNDQVIST C, BORIANI G, CASTELLA M, DAN GA, POLYCHRONIS E DILAVERIS PE, FAUCHIER L, FILIPPATOS G, KALMAN J, LA MEIR M, LANE DA, LEBEAU JP, LETTINO M, LIP GY, PINTO FJ, THOMAS N, VALGIMIGLI M, VAN GELDER IC, VAN PUTTE BP, WATKINS CL, Eur Heart J, 2020. DOI: 10.1093/eurheartj/ehaa612. - 2. SARAH S, J Clin Pharmacol, 53/1 (2013) 1. DOI: 10.1177/0091270011432169. - 3. PISTERS R, LANE DA, NIEUWLAAT R, DE VOS CB, CRIJNS HJ, LIP GY, Chest, 138/5 (2010) 1093. DOI: 10.1378/chest.10-0134. - 4. FREEDMAN B, POTPARA TS, LIP GY, Lancet, 388 (2016) 806. DOI: 10.1016/S01406736(16)31257-0. - 5. RUFF CT, GIUGLIANO RP, BRAUNWALD E, HOFFMAN EB, DEENADAYALU N, EZEKOWITZ MD, CAMM AJ, JEFFREY WEITZ JI, LEWIS BS, PARKHOMENKO A, YAMASHITA T, ANTMAN EM, Lancet, 383 (2014) 955. DOI: 10.1016/S01406736(13)62343-0. - 6. CONNOLLY SJ, EZEKOWITZ MD, YUSUF S, EIKELBOOM J, OLDGREN J, PAREKH A, POGUE J, REILLY PA, THEMELES E, VARRONE J, WANG S, ALINGS M, XAVIER D, ZHU J, DIAZ R, LEWIS BS, DARIUS H, DIENER HC, JOYNER CD, LARS WALLENTIN L, N Engl J Med, 361/12 (2009) 1139. DOI: 10.1056/NEJMoa0905561. - 7. GRANGER CB, ALEXANDER JH, MCMURRAY JJ, LOPES RD, HYLEK EM, HANNA M, AL-KHALIDI HR, ANSELL J, ATAR D, AVEZUM A, BAHIT MC, DIAZ R, EASTON JD, EZEKOWITZ JA, FLAKER G, GARCIA D, GERALDES M, GERSH BJ, GOLITSYN S, GOTO S, HERMOSILLO AG, HOHNLOSER SH, HOROWITZ J, MOHAN P, JANSKY P, LEWIS BS, LOPEZ-SENDON JL, PAIS P, PARKHOMENKO A, VERHEUGT FWA, ZHU J, WALLENTIN L , N Engl J Med, 365/11 (2011) 981. DOI: 10.1056/NEJMoa1107039. - 8.PATEL MR, MAHAFFEY KW, GARG J, PAN G, SINGER DE, HACKE W, BREITHARDT G, HALPERIN JL, HANKEY GJ, PICCINI JP, BECKER RC, NESSEL CC, PAOLINI JF, BERKOWITZ SD, FOX KAA, CALIFF RM, N Engl J Med, 365/10 (2011) 883. DOI: 10.1056/NEJMoa1009638. - 9. GIUGLIANO RP, RUFF CT, BRAUNWALD E, MURPHY SA, WIVIOTT SD, HALPERIN JL, WALDO AL, EZEKOWITZ MD, WEITZ JI, ŠPINAR J, RUZYLLO W, RUDA M, KORETSUNE Y, BETCHER J, SHI
M, GRIP LT, PATEL SP, PATEL I, HANYOK JJ, MERCURI M, ANTMAN EM, N Engl J Med, 369/22 (2013) 2093. DOI: 10.1056/NEJ. Moa1310907. - 10. MEKAJ YH, MEKAJ AY, DUCI SB, MIFTARI EI, Ther Clin Risk Manag, 11 (2015) 967. DOI:10.2147/TCRM.S84210. — 11. WAKS JW, ZIMETBAUM PJ, Expert Rev Cardiovasc Ther, 11 (2013) 1461. DOI:10.1586/14779072.2013.849572. — 12. COMIN J, KALLMES DF, AJNR Am J Neuroradiol, 33/3 (2012) 426. DOI: 10.3174/ajnr.A3000. - 13. STANGIER J, Clin Pharmacokinet, $47 / 5$ (2008) 285. DOI 10.2165/00003088-200847050-00001. - 14. BARTON CA, MCMILLIAN WD, RAZA SS, KELLER RE, Pharmacotherapy, 32/5 (2012) e103. DOI:10.1002/j.1875-9114.2012.01036.x. - 15. ABDALLAH M, ABDALLAH T, ABI RAFEH N, KHOUEIRY G, ABOUYASSINE A, CHALHOUB M, ELSAYEGH D, SASSO L, Heart Lung, 44/3 (2015) 209. DOI:10.1016/j.hrtlng.2015.02.006. - 16. DOĞAN NÖ, PAMUKÇU GÜNAYDIN G, TEKIN M, CEVIK Y, Case Rep Emerg Med, (2013) 546024. DOI:10.1155/2013/546024. - 17. ROSTAND RA, FELDMAN RL, BLOCK ER, South Med J, 70/9 (1977) 1128. DOI: 10.1097/00007611197709000-00037. - 18. CINELLI M, UDDIN A, DUKA I, SOOMRO A, TAMBURRINO F, GHAVAMI F, LAFFERTY J, Cardiol Res, 10/4 (2019) 249. DOI:10.14740/cr902. - 19. AKGEDIK R, GÜNAYDIN Z, BEKTAS O, KARAGÖZ A, ÖZTÜRK H, Clin Respir J, 11/3 (2017) 394. DOI: 10.1111/crj.12327. — 20. SYED YY, Am J Cardiovasc Drugs, 16/4 (2016) 297. DOI: 10.1007/s40256-016-0181-4. — 21. POLLACK CV JR, REILLY PA, EIKELBOOM J, GLUND S, VERHAMME P, BERNSTEIN RA, DUBIEL R, HUISMAN MV, HYLEK EM, KAMPHUISEN PW, KREUZER J, LEVY JH, SELLKE FW, STANGIER J, STEINER T, WANG B, KAM CW, WEITZET JI, N Engl J Med, 373 (2015) 511. DOI: 10.1056/NEJMoa1502000 — 22. LUCIJANIC M, JURIN I, JURIN H, LUCIJANIC T, STARCEVIC B, SKELIN M, GLASNOVIC A, CATIC J, JURISIC A, HADZIBEGOVIC I, Int. J. Cardiol, 301 (2019) 90. DOI: 10.1016/j.ijcard.2019.10.035 — 23. LUCIJANIC M, SKELIN M, JURIN I, HADZIBEGOVIC I, Int J Cardiol, 312 (2020) 107. DOI: 10.1016/j.ijcard.2020.04.064. - 24. Y.H. LIP G, KESHISHIAN A, LI X, HAMILTON M, MASSERIA C, GUPTA K, LUO X, MARDEKIAN J, FRIEND K, NADKARNI A, PAN X, BASER O, DEITELZWEIG S, Stroke, 49/12 (2018) 2933. DOI: 10.1161/STROKEAHA.118.020232. 


\section{J. Katić}

Department of Cardiology, University Hospital Centre Split, Spinciceva 1, 21000 Split, Croatia

E-mail: josipkatic@gmail.com

\section{TERAPIJA DABIGATRANOM KAO UZROK ISTOVREMENOG HEMOPERIKARDA I HEMOTORAKSA: PRIKAZ SLUČAJA}

\section{S A Ž E T A K}

Istodobno spontani hemoperikard i hemotoraks tijekom primjene oralnih antikoagulanata izuzetno je rijetka pojava u kliničkoj praksi. Dabigatran je oralni izravni inhibitor trombina odobren za prevenciju moždanog udara ili tromboembolijskih događaja u bolesnika s nevalvularnom fibrilacijom atrija. Prikazan je slučaj 73-godišnjaka na terapiji dabigatranom (150 mg dva puta dnevno) od 3 mjeseca sa razvojem masivnog spontanog hemotoraksa i hemoperikarda praćeno vrućicom. Višeslojna kompjutorizirana tomografija (MSCT) toraksa je pokazala perikardijalni izljev veće gustoće (22HU) kao lijevi pleuralni izljev heterogene gustoće (5-15 HU), opisano kao mogući hemoragični sadržaj, dok je nalaz ultrazvuka srca verificirao perikardijalni izljev od 7-9 mm, bez utjecaja na hemodinamiku. Torakocentezom se evakuira gotovo $1100 \mathrm{ml} \mathrm{krvi.} \mathrm{Urađenom} \mathrm{kliničkom} \mathrm{obradom} \mathrm{isključeni} \mathrm{su} \mathrm{drugi} \mathrm{uzroci} \mathrm{te} \mathrm{se} \mathrm{izostavljanjem} \mathrm{dabigatrana} \mathrm{iz} \mathrm{terapije}$ prekinulo daljnje nakupljanje krvi u perikard ili pleuralni prostor. Tijekom primjene dabigatrana moguć je potencijalni nastanak hemoragičnih komplikacija na koje svakako treba pomišljati. 